\title{
アルミニゥム合金の添加元素が鉄に対する 濡レに及ぼす影響
}

\section{堀 口貞 雄* · 大 野 篤 美* \\ Effect of Alloying Elements on Spreading Aluminium Alloy over Iron \\ Sadao HORIGUCH* \& Atsumi OHNO*}

The pieces $(3 \mathrm{~mm} \phi \times 5 \mathrm{~mm})$ of aluminium alloys containing $\mathrm{Ag}, \mathrm{Be}, \mathrm{Bi}, \mathrm{Ca}, \mathrm{Cd}, \mathrm{Co}, \mathrm{Cr}, \mathrm{Cu}$, In, $\mathrm{K}, \mathrm{Li}, \mathrm{Mg}, \mathrm{Mn}, \mathrm{Mo}, \mathrm{Na}, \mathrm{Ni}, \mathrm{Pb}, \mathrm{Sb}, \mathrm{Se}, \mathrm{Si}, \mathrm{Sn}, \mathrm{Te}, \mathrm{Ti}, \mathrm{Tl}, \mathrm{Zr}$ were put respectively on the iron dish with $\mathrm{KF}-54.2 \% \mathrm{AlF}$ flux and heated at $680^{\circ} \mathrm{C}$ for $2 \mathrm{~min}$ in an electric furnace.

The area of aluminium alloy spreaded over the iron dish were measured by the planimeter. As a result, Bi was the most effective element for spreading aluminium alloy over iron.

\section{1. 緒言}

一般にアルミニウムメッキ法は溶融アルミニウムまた はアルミニウム合金中に鉄鋼を浸セキして，その表面を アルミニウムあるいはアルミニウム合金で被覆し，その 耐食性およで耐高温酸化性を改善せんとするもので，フ ルミナイズド鋼に要求される主な点は次のと打りであ る。

i ）ピンホールのできないこと。

ii）加工性が良いこと。

iii）メッキ層自身の耐食性が良いこと。

iv）鉄素地とメッキ層との間の電池構成による腐食が 少ないこと。

v)メッキが均一であること。

上記の条件を満足させるためには次の上うな研究が必 要と考兄られる。
A. 適当な前処理法を見出すこと。
B. 適当なアルミニウム浴組成を見出すこと。
C．適当な浸セキ条件を見出すこと。
D. 適当な後処理を施すこと。

著者らはB 項について研究を試みたが，B項はさらに 次のように分けて考光られる。

1）優れた耐食性を与兄る適当な浴組成を見出すこ そ。

2）需レに効果のある添加元素を見出すこと。

今回は特に後者について報告する。

一般にアルミニウム浴に鉄を浸セキ寸る際にはゼイ弱 な中間層をできるだけ薄くし，しかもアルミニウムが均 一に平滑にから迅速に鉄を濡らさなけ斿ばならない。

一般に中間層の厚サは主としてアルミニウム浴の成

*千葉工業大学 (千葉県習志野市谷津)

Chiba Institute of Technology
分, 粘性, および温度, 浸セキ時間, 引上ゲ速度, 冷却 速度などに関係していると言われ，中間層の成長につい ては多くの研究がなされている。

中間層に対する各種の浴添加元素の影響は $\mathrm{Sb}, \mathrm{Be}$, $\mathrm{Bi}, \mathrm{Cd}, \mathrm{Ca}, \mathrm{Cr}, \mathrm{Co}, \mathrm{Cu}, \mathrm{Ge}, \mathrm{Pb}, \mathrm{Mg}, \mathrm{Mn}, \mathrm{Ni}, \mathrm{Si}$, $\mathrm{Ag}, \mathrm{Sn}, \mathrm{Ti}$ および $\mathrm{Zr}$ について行なわれた実験の結果， $\mathrm{Si}, \mathrm{Cu}, \mathrm{Be}$ のみが中間層の厚サを $50 \%$ 以上減じ， $\mathrm{Si}$ お よび Be は中間層のカタサを減じ被覆を改善し, Be は $\mathrm{Si}$ よりさらに効果的であったが， $\mathrm{Bi}, \mathrm{Ca}, \mathrm{Cu}, \mathrm{Ge}$, $\mathrm{Mg}, \mathrm{Ni}, \mathrm{Si}, \mathrm{Sn}, \mathrm{Zr}$ は純アルミニウムメッキの外観 に比べて好ましいものでなかったことが報告されてい る1) 2) 3) 4)。

しかしながら濡レに対するこれら元素の影響について は，汪とんぞ報告を見ることができない。

鉄に対するアルミニウムの濡レは浸セキの際のアルミ ニウムと鉄間に抢ける界面張力やその際のアルミニウム の粘性などに左右されると考えられるが，著者らはまず 鉄に対し，いかなる元素を添加されたアルミニウム合金 が，濡レに対しょり優れた効喿があるかを，以下に述べ る方法で検討した。

\section{2. 実験装置および方法}

本実験に扮いては種々の元素を少量添加した一定体積 を有するアルミニウム合金の試料を作り，鉄皿上に一定 量のフラックスとともに載せ，これを電父炉中に水平に 插入し短時間保持後引出して鉄且上でのアルミニウムの 濡レ拡がり面䅡を測定する方法を用いた。

まず約 $20 \mathrm{~g}$ の純度 $99.99 \%$ のアルミニウムを黑鉛ル ッボで溶解し，これに第 1 表のような種々の元素を添加 し，直径 $3 \mathrm{~mm}$ のアルミニウム合金棒を鋳造し，これを 約 $5 \mathrm{~mm}$ に切断し，両面をさらにヤスリで仕上げ，マイ クロメーターで測定し正しく5 mm になるようにした。 
第 1 表 满レ面積の測定結果

\begin{tabular}{|c|c|c|c|c|c|c|}
\hline \multirow{2}{*}{$\begin{array}{l}\text { 添 加 } \\
\text { 元素名 }\end{array}$} & \multirow{2}{*}{$\begin{array}{c}\text { 添加 } \\
\%\end{array}$} & \multicolumn{3}{|c|}{$\begin{array}{c}\text { 濡レ面積の測定値 } \\
\left(\mathrm{cm}^{2}\right)\end{array}$} & \multirow{2}{*}{$\begin{array}{c}\text { 平均面積 } \\
\left(\mathrm{cm}^{2}\right)\end{array}$} & \multirow{2}{*}{ 面積比 } \\
\hline & & A & B & $\mathrm{C}$ & & \\
\hline $\mathrm{Al}$ & & 6.3 & 6.5 & 6.7 & 6.5 & 1.0 \\
\hline $\mathrm{Ag}$ & 0.5 & 7.4 & 8.4 & 6.8 & 7.6 & 1.1 \\
\hline $\mathrm{Bi}$ & 1.0 & 7.3 & 12.2 & 5.1 & 8.2 & 1.3 \\
\hline $\mathrm{Bi}$ & 0.5 & $12.1 \%$ & $7.0 \%$ & $8.9 \%$ & $9.3 \%$ & $1.4 \%$ \\
\hline $\mathrm{Bi}$ & 0.3 & 10.6 & 10.1 & 9.0 & 9.9 & 1.5 \\
\hline $\mathrm{Bi}$ & 0.1 & $6.9 \%$ & $9.3 \%$ & $9.6 \%$ & $8.6 \%$ & $1.3 \%$ \\
\hline $\mathrm{Bi}$ & 0.05 & $11.8 \%$ & $8.4 \%$ & $9.6 \%$ & $9.9 \%$ & $1.5 \%$ \\
\hline $\mathrm{Bi}$ & 0.01 & 5.4 & 7.4 & 6.6 & 6.5 & 1.0 \\
\hline $\mathrm{Be}$ & 0.2 & 4.2 & 4.4 & 6.0 & 4.9 & 0.8 \\
\hline $\mathrm{Ca}$ & 0.5 & 8.9 & 8.5 & 7.5 & 8.3 & 1.3 \\
\hline $\mathrm{Ca}$ & 0.1 & 5.7 & 4.5 & 7.1 & 5.8 & 0.9 \\
\hline $\mathrm{Cd}$ & 1.0 & 5.2 & 4.5 & 4.3 & 4.7 & 0.6 \\
\hline $\mathrm{Cd}$ & 0.5 & 8.9 & 8.5 & 7.5 & 8.3 & 1.3 \\
\hline $\mathrm{Cd}$ & 0.1 & 6.9 & 5.2 & 5.6 & 5.8 & 0.9 \\
\hline $\mathrm{Co}$ & 100 & 6.5 & 4.7 & 6.2 & 5.8 & 0.9 \\
\hline Co & 0.5 & 3.1 & 3.2 & 4.0 & 3.4 & 0.5 \\
\hline Co & 0.1 & 4.4 & 5.9 & 5.2 & 5.2 & 0.8 \\
\hline $\mathrm{Cr}$ & 1.0 & 3.5 & 4.0 & 2.7 & 3.4 & 0.5 \\
\hline $\mathrm{Cr}$ & 0.5 & 5.0 & 7.9 & 6.0 & 6.3 & 1.0 \\
\hline $\mathrm{Cr}$ & 0.1 & 7.0 & 6.2 & 6.0 & 6.4 & 1.0 \\
\hline $\mathrm{Cu}$ & 2.0 & 4.3 & 3.1 & 2.7 & 3.4 & 0.5 \\
\hline $\mathrm{Cu}$ & 1.0 & 9.1 & 6.3 & 8.2 & 7.9 & 1.2 \\
\hline $\mathrm{Cu}$ & 0.5 & 6.5 & 6.3 & 9.1 & 7.3 & 1.1 \\
\hline $\mathrm{Cu}$ & 0.1 & 2.3 & 5.6 & 4.1 & 4.0 & 0.6 \\
\hline I n & 0.5 & 10.0 & 8.2 & 7.0 & 8.4 & 1.3 \\
\hline I n & 0.1 & 7.2 & 6.8 & 9.5 & 7.8 & 1.2 \\
\hline $\mathrm{K}$ & 1.0 & 6.6 & 5.5 & 5.5 & 6.2 & 0.9 \\
\hline $\mathrm{K}$ & 0.1 & 6.0 & 5.7 & 8.0 & 6.5 & 1.0 \\
\hline $\mathrm{Li}$ & 1.0 & 8.0 & 7.9 & 6.0 & 7.3 & 1.1 \\
\hline $\mathrm{Li}$ & 0.1 & 6.7 & 4.8 & 9.4 & 7.0 & 1.1 \\
\hline $\mathrm{Mg}$ & 1.0 & 5.9 & 6.0 & 5.0 & 5.6 & 0.8 \\
\hline $\mathrm{Mg}$ & 0.5 & 7.1 & 8.0 & 7.5 & 7.5 & 1.2 \\
\hline $\mathrm{Mg}$ & 0.1 & 6.8 & 9.0 & 8.2 & 8.0 & 1.2 \\
\hline $\mathrm{Mn}$ & 0.5 & 5.3 & 6.0 & 5.0 & 5.4 & 0.8 \\
\hline $\mathrm{Mn}$ & 0.1 & 8.4 & 7.5 & 7.7 & 7.9 & 1.2 \\
\hline Mo & 0.5 & 7.2 & 7.2 & 5.0 & 6.6 & 1.0 \\
\hline Mo & 0.1 & 5.5 & 3.8 & 3.0 & 4.1 & 0.6 \\
\hline $\mathrm{Na}$ & 1.0 & 6.5 & 5.8 & 5.4 & 5.9 & 0.9 \\
\hline $\mathrm{Na}$ & 0.1 & 7.2 & 7.0 & 5.4 & 6.5 & 1.0 \\
\hline $\mathrm{Ni}$ & 2.0 & 4.0 & 5.9 & 4.8 & 4.9 & 0.8 \\
\hline $\mathrm{Ni}$ & 0.5 & 6.9 & 5.5 & 6.4 & 6.3 & 1.0 \\
\hline $\mathrm{Ni}$ & 0.1 & 5.0 & 5.3 & 5.7 & 5.3 & 0.8 \\
\hline $\mathrm{Pb}$ & 0.5 & 5.1 & 9.7 & 7.8 & 7.5 & 1.2 \\
\hline $\mathrm{Pb}$ & 0.1 & 6.1 & 6.3 & 8.0 & 6.8 & 1.0 \\
\hline Sb & 1.0 & 3.2 & 3.5 & 3.5 & 4.6 & 0.7 \\
\hline $\mathrm{Sb}$ & 0.5 & 4.5 & 6.5 & 4.2 & 5.0 & 0.8 \\
\hline Sb & 0.1 & 7.8 & 6.6 & 10.4 & 8.3 & 1.3 \\
\hline
\end{tabular}

\begin{tabular}{|c|c|c|c|c|c|c|}
\hline 添 加 & 添加 & 消采 & $(\mathrm{cm}$ & . & 平均面積 & 面皘比 \\
\hline 元桑名 & $\%$ & A & B & $\mathrm{C}$ & $\left(\mathrm{cm}^{2}\right)$ & \\
\hline $\mathrm{Se}$ & 0.5 & 8.8 & 7.9 & 8.2 & 8.3 & 1.3 \\
\hline $\mathrm{Se}$ & 0.1 & 8.6 & 8.2 & 8.0 & 8.3 & 1.3 \\
\hline $\mathrm{Si}$ & 1.0 & 4.8 & 4.8 & 4.3 & 4.6 & 0.7 \\
\hline $\mathrm{Si}$ & 0.5 & 5.4 & 5.3 & 5.5 & 5.4 & 0.8 \\
\hline $\mathrm{Si}$ & 0.1 & 6.2 & 6.8 & 5.7 & 6.2 & 1.0 \\
\hline $\mathrm{Sn}$ & 1.0 & 3.3 & 3.9 & 3.4 & 3.5 & 0.5 \\
\hline $\mathrm{Sn}$ & 0.5 & 3.3 & 4.5 & 4.7 & 4.1 & 0.6 \\
\hline $\mathrm{Sn}$ & 0.1 & 6.2 & 5.7 & 6.1 & 6.0 & 0.9 \\
\hline $\mathrm{Te}$ & 0.5 & 5.8 & 7.0 & 6.5 & 6.4 & 1.0 \\
\hline $\mathrm{Te}$ & 0.1 & 5.5 & 2.8 & 2.5 & 3.5 & 0.5 \\
\hline $\mathrm{Ti}$ & 1.0 & 5.5 & 6.8 & 5.9 & 6.1 & 1.0 \\
\hline $\mathrm{Ti}$ & 0.5 & 4.9 & 5.6 & 4.5 & 5.0 & 0.8 \\
\hline $\mathrm{Ti}$ & 0.1 & 9.7 & 7.7 & 7.1 & 8.2 & 1.3 \\
\hline $\mathrm{Tl}$ & 0.5 & 6.5 & 6.7 & 5.7 & 6.3 & 1.0 \\
\hline $\mathrm{Tl}$ & 0.1 & 7.0 & 6.8 & 5.2 & 6.3 & $\therefore .0$ \\
\hline $\mathrm{Zr}$ & 1 & 4.5 & 4.7 & 4.9 & 4.7 & 0.7 \\
\hline $\mathrm{Zr}$ & 0.5 & 4.6 & 4.7 & 4.3 & 4.5 & 0.7 \\
\hline $\mathrm{Zr}$ & 0.1 & 3.4 & 4.9 & 3.2 & 3.8 & 0.5 \\
\hline * i f & アル & & & & 사. $\mathrm{mI}$ & ま \\
\hline
\end{tabular}

また使用した鉄皿は擪サ $0.5 \mathrm{~mm}$ の鉄板（C $0.07 \% ，$ Mn 0.35\%, P 0.08\%，S 0.033\%）を一辺 $57.5 \mathrm{~mm}$ の正方形に切断し, 深サ $3 \mathrm{~mm}$, 直径 $50 \mathrm{~mm}$ の皿状に プレスした。プレスした皿は1翻のエメリペーパーで表 面を研摩し，さらにシンナーおよび·10\% $\mathrm{NaOH}$ 水溶液 で脱脂処理を行なった。

この鉄IIIL上にフックスとして $\mathrm{KF}-54.2 \% \mathrm{AlF}_{3}$ を $2 \mathrm{~g}$ 均一になるようにのせ，その中央に上記アルミニウ ム合金の試料を置き，次にこれを第 1 図のよ5な電気炉 中に插入した。アルミニウムメッキに際し，成形性を良 好ならしめるためにはゼイ弱な合金層の成長は最小に留 めねばならない。そのためには鉄をアルミニウム浴に浸 セキする場合，アルミニウム浴の温度はその融点 $660^{\circ} \mathrm{C}$

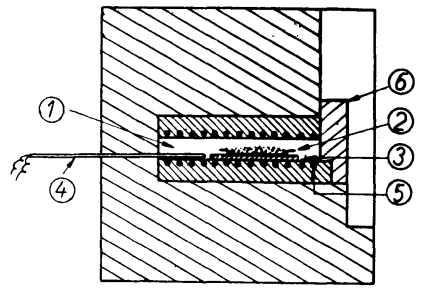
(1) 加熱室 $(120 \mathrm{~mm} \times$ $120 \mathrm{~mm} \times 20 \mathrm{~mm}$ )
(2) 鉄血
(3) 石綿板 (50 $\mathrm{mm} \times$ $70 \mathrm{~mm} \times 3 \mathrm{~mm}$ )
(4) 熱電対
(5) 発熱体（ニクロム 線)
(6) ふた


に近いことが必要で，かつより短い浸セキ時間が必要と 考えられる。しかしながら融点にきわめて近い温度で は, アルミニウム合全の濡レを短時間に明確に比較する ことが困難であったため, 実験操作上 $680^{\circ} \mathrm{C}$ で加熱時間 を $2 \mathrm{~min}$ に一定した。な教鉄且上の温度が常に $680^{\circ} \mathrm{C}$ に なるように炉内の温度を調節した。 $2 \mathrm{~min}$ 間㭁中で $680^{\circ} \mathrm{C}$ に保持した鉄且は直ちに水平に保ちつつ炣外に取出し， 空冷後フラックスを除去し，アルミニウム合金の濡レ面 積をプラニメーターで測定した。

\section{3. 実験結果と考察}

以上に述べた方法によって，鉄皿上におけるアルミニ ウム合金の濡レ面積を測定した結果は第 1 表である。表 に示す面積比は純アルミニウムの濡レ面積を1 として示 したものである。なおここで $\mathrm{Li}, \mathrm{Na}, \mathrm{K}$ はアルミニ ウムに添加する際に浮上然焼し 溶入が 困難であったた め, 希望する添加量が得られず，処理程度の合金しか得 られなかったと思われる。また表中※印を付したもの は，実際の需レ面積が表の偭よりいくぶん大になると考 えられるが，比較の大勢にはさ汪ど大きな变化をあたえ ないと考觉る。

本実験の結果少量の $\mathrm{Bi}$ の添加がアルミニウムの需レ に特にいちじるしい効果のあることが明らかになった。 Bi は 0.05\% の添加で，すでに純アルミニウムによる 濡レ面積の 1.5 倍を示した。 $\mathrm{Bi}-\mathrm{Al}$ 系合金は偏晶反応を 有し $271^{\circ} \mathrm{C}$ の低温まで液相が存在するために，良く濡れ たのではあるまいかとの想定にもとずき，同様の合金状 態図を有する $\mathrm{Cd}, \mathrm{In}, \mathrm{K}, \mathrm{Na}, \mathrm{Pb}, \mathrm{Tl}$ を選んで同様の 実験を試みたが，必ずしも偏晶反応と濡レとの間になん らかの関係があるような結果は得られず，また Bi 活ど の効果を示すものは見出せなかった。それゆ党に Bi 添
加による優れた濡レは単に液相が低温まで存在すること 以外に， Bi の添加のためにアルミニウム合金の表面張 カがいセじるしく小になったことが大きな原因のように 考えられる。この Bi 添加の効果の理由についてはさら 汇今後の研究にまたねばならないが，鉄に対するアルミ ニウムの溶融メッキに際し, 少量の Bi 添加浴の使用に より浸セキ温度をアルミニウムの融点近くにまで下げ ることができ，さらに浸セキ時間をいちじるしく短縮す ることが可能となり, 中間層のきわめて薄いアルミナイ ズド鋼の製造を容易にするとともに生産能率を高めるこ とができると考える。

\section{4. 総括}

鉄に対するアルミニウムの溶融メッキに際し，鉄に対 するアルミニゥム合金の濡レに効果のある添加元素を見 出すために, 直径 $50 \mathrm{~mm}$ の鉄血上に $\mathrm{KF}-\mathrm{AlF}_{3} 2 \mathrm{~g}$ と ともに直径 $3 \mathrm{~mm}$, 長サ $5 \mathrm{~mm}$ のアルミニウム合金試 料を置き， $680^{\circ} \mathrm{C}$ に $2 \mathrm{~min}$ 間加熱した後，鉄皿上での アルミニウム合金の濡レ面積を比較し，アルミニウムに 対する少量の添加元素が，需レにいかなる影響をあたえ るかを調べた結果, 少量の Bi の添加がアルミニウム合 金の需レにいちじるしい効果のあることを知った。

(1959.6.4 受理)

\section{文献}

(1) P. T. Stroup and G. A. Purdy, Metal Progress, 59, Jan. (1950)

(2) W. Hodge, Materials \& Methods, Sept.(1951), 95-96.

(3) J. B. Russell, Steel, July 14 (1952), 100

(4) D. O. Gittings, D. H. Rowland and J. O. Mack, Materials \& Methods, Dec. (1950), 110

\section{第 6 回ポーラログラフ討論会}

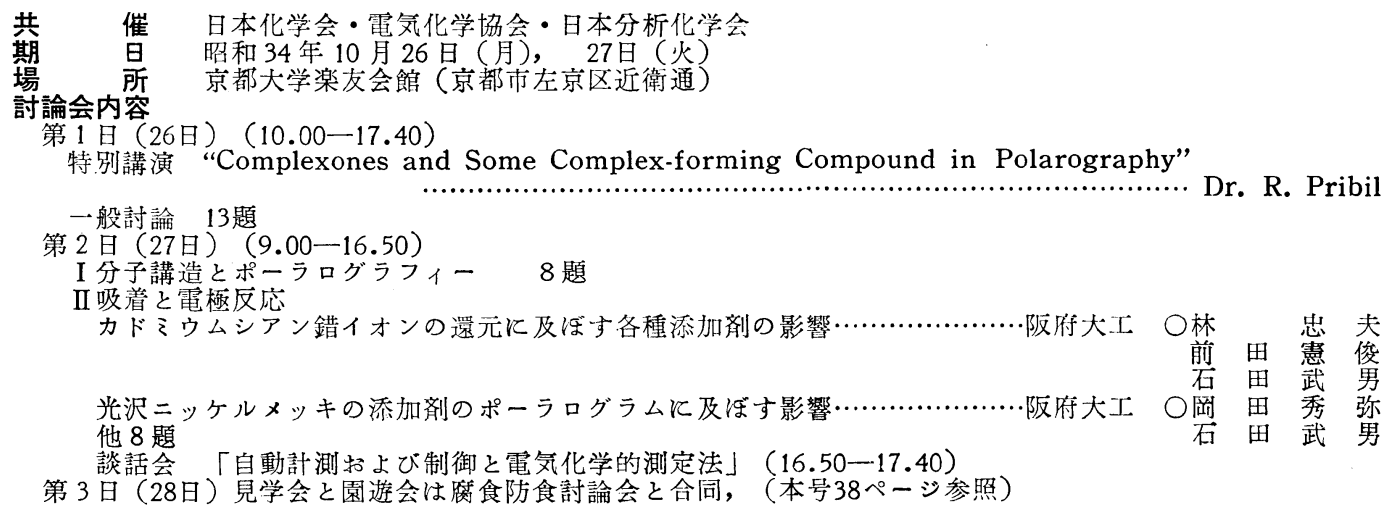

